\title{
Capital Structure and Financial Performance of Manufacturing Companies in Indonesia
}

\author{
Ni Luh Ira Suitri ${ }^{1}$ \\ ${ }^{1}$ Department of Management-Economic Faculty-Universitas Negeri Gorontalo-Indonesia \\ Mohamad Agus Salim Monoarfa ${ }^{2}$, Srie Isnawaty Pakaya ${ }^{3}$ \\ ${ }^{2}$ Department of Management-Economic Faculty-Universitas Negeri Gorontalo-Indonesia \\ ${ }^{3}$ Department of Management-Economic Faculty-Universitas Negeri Gorontalo-Indonesia
}

\section{Correspondence:irasuitri99@gmail.com}

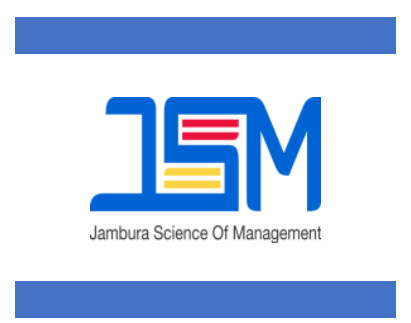

JSM

Volume 3

Number 2

July 2021.

Received on 06 July 2021

Revised on 14 July 2021

Accepted on 15 July 2021

The journal allows the

authors to hold the copyright

without restrictions and

allow the authors to retain

publishing rights without

restrictions. Authors retain

copyright and grant the

journal right of first

publication with the work

simultaneously licensed

under a creative commons

attribution 4.0 international

license.

\section{(C) (1)}

DOI: 10.37479

\section{ABSTRACT}

Purpose: This study aims to determine whether the Capital Structure affects the financial performances partially and simultaneouslly. The Capital Structure in this study is proxide by Debt to Asset Ratio (DAR) and Long Term Debt to Equity Ratio (LTDER), whereas the financial performance is proxide by Return on Asset (ROA).

Design/Methodology/Approarch: The type of data used in this study is secondary data obtained from the financial statements os plastic and packaging companies listed on the Indonesia Stock Exchange in 2012-2019. The analysis method uses multiple linier regression analysis.

Findings: The result revealed that partially DAR had negative and significant effect on ROA, while LTDER had no significant effect on ROA. The result also shows that simultaneouslly DAR and LTDER have a significant effect on ROA.

Keywords: Capital Structure; Financial Performance; DAR; LTDER; ROA.

\section{INTRODUCTION}

Currently, the business and business sector is the sector that is most widely discussed, both on a national and international scale. Along with business development, it encourages companies from various industries to grow more competitively in order to maintain their existence (Fadhilah, 2012). One sector that is developing is the manufacturing sector. The manufacturing sector is an industrial sector that manages raw materials into semi-finished materials or finished goods. The manufacturing sector produces products needed for daily needs. The manufacturing sector is divided into three main sectors, namely the basic and chemical industry sector, the various industrial sector and the consumer goods sector. Among the three sectors, the sectors that will continue to develop are the basic and chemical industries.

P-ISSN: 2655-3651 E-ISSN: 2656-0435 $P$ a g e | 114 
The basic and chemical sector produces basic raw materials and chemicals. There are several sections of the basic and chemical sector, one of which is the plastics and packaging sector. The plastics and packaging sector is a sector that affects other sectors because almost all manufacturing sectors require plastics and packaging. Based on the National Industrial Development Master Plan (RIPIN), the Ministry of Industry has determined the downstream plastic industry as a priority sector for development in 2015 to 2019. This is why companies must be able to maximize their company's financial performance.

The company's financial performance is a financial condition that is influenced by the management decision-making process (Kristianti, 2018). Financial performance is needed by companies to find out and evaluate the extent to which the company's success rate is based on the financial activities carried out. Financial performance can be a reflection or benchmark for the success of the company's management in achieving company goals.

Whether or not a company's financial performance can be seen from the company's profitability ratios. One part of the profitability ratios that can be used to analyze the company's financial performance is the Return On Assets (ROA). Return on Assets (ROA) is a measure of profitability that is better than other ratios that show the effectiveness of the company in using assets in accordance with its control to create income (Tangkilisan, 2003:251).

The importance of the plastics and packaging sector for other sectors causes other sectors to have a dependence on plastic and packaging companies. The dependence of other sectors on the plastics and packaging sector should be able to make the plastics and packaging sector a sector that has the potential to generate good profits due to the demand for products from other sectors. However, profit growth from the plastics and packaging sector is still volatile. This can be seen from the average Return On Asset (ROA) data for plastic and packaging companies listed on the Indonesia Stock Exchange from 2012 to 2019.

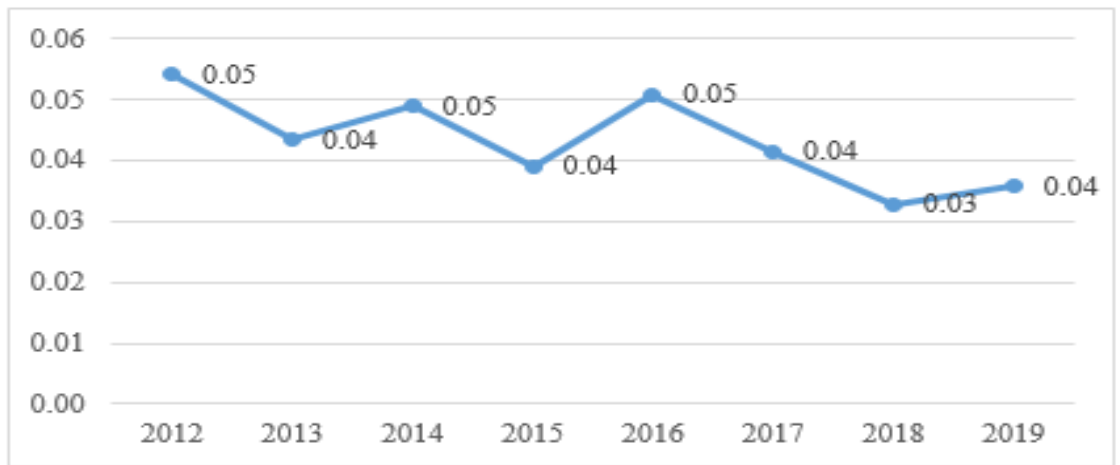

Figure 1. Average Return on Assets (ROA) of Plastic and Packaging Companies for the Period 2012-2019 (Data Processed, 2021) 
The phenomenon of fluctuations in the average Return On Asset (ROA) value in plastic and packaging companies listed on the Indonesia Stock Exchange is certainly influenced by several factors. One of the factors that affect the financial performance (ROA) of plastic and packaging companies is the company's capital structure. The company's capital structure describes the comparison between the amount of debt and equity capital used by the company (Gitman, 2003). The company's capital structure is a decision taken in choosing own capital or outside party funds (debt) to finance the company's operations. Companies that want to expand their business can choose to use debt to increase business capital because it is not permanent and cheaper than if the company had to issue new shares.

The use of debt can provide several advantages for the company. One of the benefits derived from the use of debt is a tax reduction due to the interest expense resulting from the use of debt. This is supported by the theory of Modigliani and Miller (1958) which suggests that in conditions of no tax there is no transaction cost, capital structure has no effect on company performance. Furthermore, in 1963 Modigliani and Miller relaxed one of their assumptions about corporate tax that if there is a corporate tax, the use of debt will improve financial performance. This means that if there is a corporate tax condition, it will be better if the company uses debt to improve the financial performance of the company.

In addition to the benefits derived from the use of debt, there are several negative impacts of using debt. One of the impacts in the trade-off theory is that the higher the debt, the greater the probability (probability) of bankruptcy. If debt is used properly followed by sales that continue to increase, the company is able to pay interest expenses and get tax breaks, on the contrary if the use of debt is high and is not followed by an increase in sales, the company has the potential to go bankrupt because it is unable to pay interest expenses (Binangkit dan Raharjo, 2014). Companies can use the debt ratio to measure the company's ability to meet its long-term obligations. There are several ratios that are part of the debt ratio. However, researchers will only use 2 measuring tools in measuring the company's capital structure, namely Debt to Asset Ratio (DAR) and Long Term Debt to Equity Ratio (LTDER).

Debt to Asset Ratio (DAR) was chosen to measure capital structure because Debt to Asset Ratio (DAR) can measure the company's ability to manage debt which is used to finance company assets effectively. Utama dan Muid (2014) stated that the higher the Debt to Asset Ratio (DAR) the greater the financial risk faced by the company, the higher the debt because the debt carries the consequence of a fixed interest expense. Sari et al., (2019) research shows that the Debt to Asset Ratio (DAR) has a positive effect on Return On Assets (ROA), while the research of Aulia et al (2020) and Mawarsih et al (2020) shows different results, that Debt to Asset Ratio (DAR) has a negative effect 
on Return On Assets (ROA).

Another indicator that can be used to see the company's capital structure can be seen from the company's ability to meet company funding by measuring the company's long-term debt to the company's total equity or called the Long Term Debt to Equity Ratio (LTDER). Research conducted by Abor (2007) states that long-term debt tends to be more expensive, therefore if the company has a high proportion, it can cause a decrease in the company's profitability. Meanwhile, research by Ludjianto et al., (2014) shows that the Long Term Debt To Asset Ratio (LTDER) has a significant effect on Return On Assets (ROA), while research conducted by Widiyanti dan Elfina (2015) shows that the effect of Long Term Debt to Equity Ratio (LTDER) to Return On Assets (ROA) is negative and not significant. on the other hand, research that has been done by Azis dan Hartono (2017) shows that the Long Term Debt To Equity Ratio (LTDER) has no effect on Financial Performance (ROA).

Financial performance can provide information about the company's ability to manage finances and maximize its business in order to achieve company goals (Fachrudin, 2011). The company's financial performance is a description of the company's financial condition in a certain period, both regarding aspects of raising and distributing funds, which are usually measured by indicators of capital adequacy, liquidity and profitability (Jumingan, 2011).

\section{Profitability}

The profitability ratio measures the company's ability to generate profits (profitability) at a certain level of sales, assets, and share capital (Hanafi, 2016:42). According to Kasmir (2019) the profitability ratio is the ratio of the company's ability to seek profit. This ratio also provides a measure of the effectiveness of a company's management. This is indicated by the profit generated from sales and investment income. The point is that the use of this ratio shows the company's efficiency in generating profits.

\section{Return on Asset (ROA)}

Return on Assets (ROA) is a form of profitability ratio which is intended to measure the company's ability to the overall funds invested in the assets used for the company's operations to generate profits (Munawir, 2004:89). ROA is also a better measure of profitability than gross profit ratio, operating ratio, gain on sales because it measures operating efficiency. This ratio shows the effectiveness of the company in using assets in accordance with its control to create income (Tangkilisan, 2003).

\section{Capital Structure}

The capital structure is a balance of the amount of debt or an overview of the overall composition of the credit side originating from short- 
term debt, long-term debt and long-term debt with own capital which is the source of financing for a company (Sartono, 2012:225; Margaretha, 2014; and Fahmi, 2012:184).

\section{Debt to Asset Ratio (DAR)}

Debt to Asset Ratio (DAR) is a ratio that looks at the comparison of the company's debt with assets or a ratio that shows the extent to which the company's debt debt can be repaid by assets. The higher this ratio, the safer (solvable) for the company (Harahap, 2013:304; Fahmi, 2015).

\section{Long Term Debt to Equity Ratio (LTDER)}

Long Term To Equity Ratio (LTDER) is a ratio that shows the extent to which own capital guarantees all of the company's long-term debt (Hartono, 2018:13; Hery, 2012:23).

\section{METHODS}

This study uses a population of plastic and packaging companies listed on the Indonesia Stock Exchange (IDX) from 2020 to 2021 with a population of 15 companies. The method used is purposive sampling.

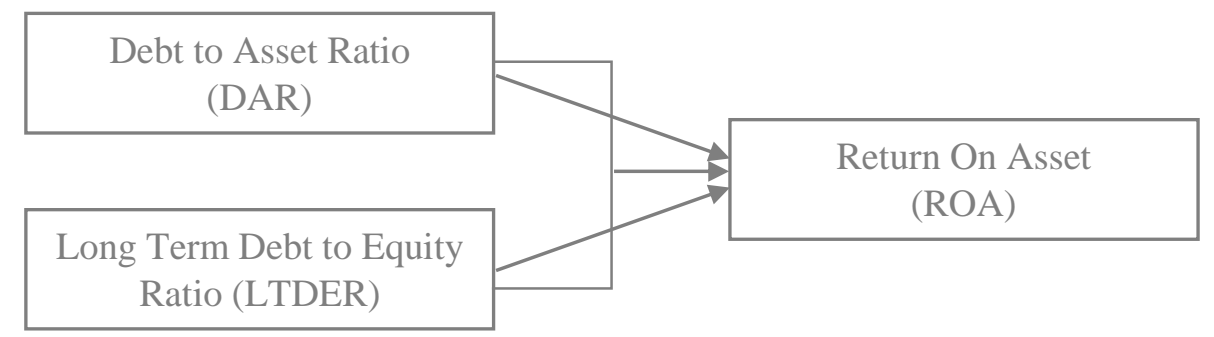

Figure 2. Research Design

\section{Hypothesis}

$\mathrm{H}_{1}$ : Capital Structure (DAR) has an effect on Financial Performance (ROA).

$\mathrm{H}_{2}$ : Capital Structure (LTDER) has an effect on Financial Performance (ROA).

$\mathrm{H}_{3}$ : Capital Structure (DAR and LTDER) simultaneously affect Financial Performance (ROA).

\section{RESULTS}

\section{Normality}

The normality test was carried out on the regression residuals. The test is carried out using the P-P Plot graph. Normal data is data that forms points that spread not far from the diagonal. The results of linear regression analysis with P-P graphs The plot of the residual error of the regression model has shown that there is a normal graph pattern, namely the distribution of points that are not far from the diagonal line as seen in Figure 3. 


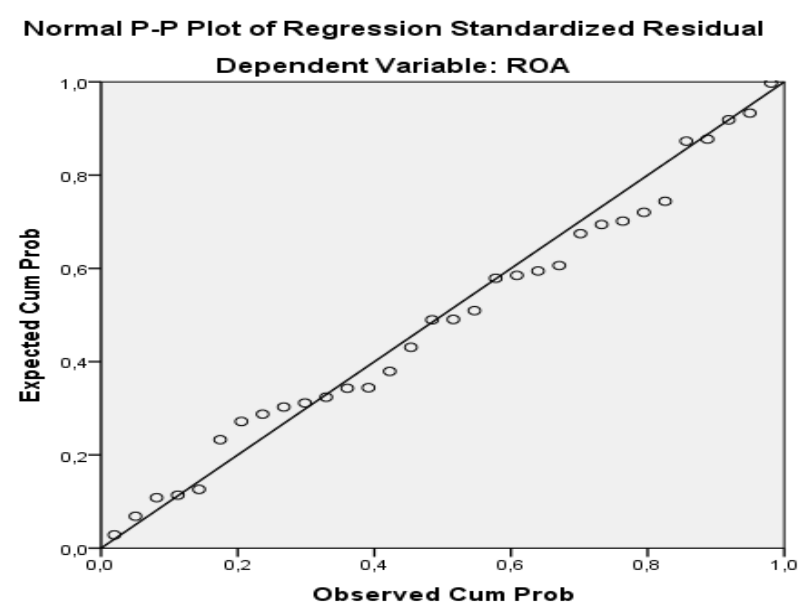

Figure 3. P-Plot (Data Processed, 2021)

\section{Multicollinearity Test}

Multicollinearity is a violation of ideal conditions caused by a linear relationship between the regressor variables. The results of the calculations in this study are as follows:

Table 1. Multicollinearity Test Result

\begin{tabular}{|l|l|c|}
\hline Variable & VIF & Tolerance \\
\hline DAR & 4,063 & 0,246 \\
\hline LTDER & 4,063 & 0,246 \\
\hline \multicolumn{2}{|c|}{ Source: Data Processed, 2021 }
\end{tabular}

Based on the above data processing, it is found that the Variance Inflation Factor (VIF) for the Debt to Asset Ratio (DAR) (X1) variable and the Long Term Debt to Equity Ratio (LTDER) (X2) variable is 4.063. The value of Variance Inflation Factor (VIF) is lower than the provision (number 10). So it is concluded that the regression model does not have multicollinearity problems so that the Debt to Asset Ratio (DAR) (X1) and Long Term Debt to Equity Ratio (LTDER) (X2) data meet the multicollinearity test.

\section{Heteroscedasticity Test}

Heteroscedasticity testing was carried out using a Scatter Plot. If the points are spread above and below the number 0 on the $\mathrm{Y}$ axis, there is no heteroscedasticity (Ghozali, 2001), as seen in Figure 4 


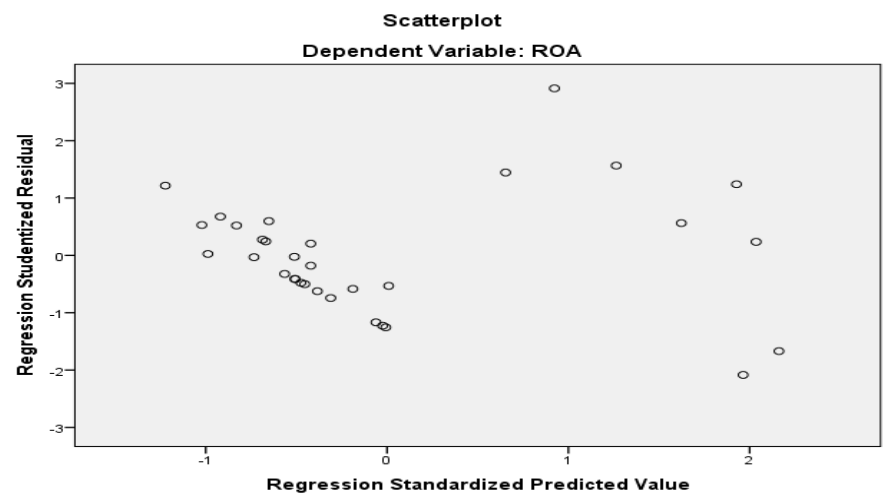

Figure 4. Scatterplot (Data Processed, 2021)

The results of the heteroscedasticity test in Figure 3 show that there is no clear pattern of dots and spreads above and below the 0 axis on the $\mathrm{Y}$ axis, this shows that the regression model does not have heteroscedasticity symptoms, which means that there is no significant disturbance in this regression model.

\section{Autocorrelation Test}

Autocorrelation arises because consecutive observations over time are related to each other. This problem arises because the residual is not independent of another observation. The autocorrelation symptom test used in this study is the Durbin-Watson, as can be seen from table 2 below:

Tabel 2. Autocorrelation Test Result

\begin{tabular}{|l|l|}
\hline Model & $\begin{array}{c}\text { Durbin- } \\
\text { Watson }\end{array}$ \\
\hline 1 & 2,309 \\
\hline
\end{tabular}

Source: Data Processed, 2021

Based on the table above, the Durbin-Watson value was obtained at 2,309 at the degree of confidence $(\alpha)=5 \%$. By using the formula du $\mathrm{D}-\mathrm{W}$ 4-du, the result is 1.57362 .309 (4-1.5736) then the result is $1.5736<2.3092 .4264$. From the results obtained that the $\mathrm{D}-\mathrm{W}$ value is between the lower limit of 1.5736 and the upper limit of 2.4264 so that the Durbin-Watson value shows that there is no autocorrelation.

\section{Multiple Regression Test}

This study uses multiple linear analysis to determine the effect of capital structure calculated using the Debt to Asset Ratio (DAR) and Long Term Debt to Equity Ratio (LTDER) on Financial Performance which is calculated using the Return On Asset (ROA) ratio. Simultaneously the test results can be seen in table 3 below. 
Table 3. Multiple Regression Test Result

\begin{tabular}{|c|c|c|}
\hline Model & B & Std. Error \\
\hline Constant & 0,189 & 0,019 \\
\hline DAR & $-0,400$ & 0,068 \\
\hline LTDER & 0,081 & 0,051 \\
\hline
\end{tabular}

Source: Data Processed, 2021

Based on table 3 above, the multiple linear regression model that can be formed is as follows:

$$
\begin{gathered}
\mathrm{Y}=\alpha+\beta_{1} \mathrm{X}_{1}+\beta_{2} \mathrm{X}_{2}+\mathrm{e} \\
\mathrm{Y}=0,189-0,400 \mathrm{X} 1+0,081 \mathrm{X} 2
\end{gathered}
$$

The equation model above can be interpreted as follows: (1) The positive constant value is 0.189 which indicates that if the DAR and LTDER variables are constant or equal to zero, it will increase ROA by 0.189 ; (2) Debt to Asset Ratio (DAR) has a negative regression coefficient of 0.400, this means that if the value of Debt to Asset Ratio (DAR) increases by 1 unit assuming other variables are fixed (cateris paribus), it will reduce Return On Assets (ROA) of 0.400; (3) Long Term Debt to Equity Ratio (LTDER) has a positive regression coefficient of 0.081, this means that if the value of Long Term Debt to Equity Ratio (LTDER) increases by 1 unit assuming other variables are fixed (cateris paribus), then will increase Return On Assets (ROA) by 0.081 .

\section{T Test}

T-test is used to determine the effect of capital structure variables (Debt to Asset Ratio and Long Term Debt to Equity Ratio) on financial performance variables (Return on Assets) partially. The results of the $t$ test can be seen in table 4 below:

Table 4. T Test Result

\begin{tabular}{|l|c|c|}
\hline \multicolumn{1}{|c|}{ Model } & T & Sig. \\
\hline Constant & 10,092 & 0,000 \\
\hline DAR & $-5,916$ & 0,000 \\
\hline LTDER & 1,598 & 0,121 \\
\hline \multicolumn{2}{|l}{ Source: Data Processed, 2021}
\end{tabular}

\section{Effect of DAR on financial performance (ROA)}

In table 4 above, it can be seen that the tcount for the Debt to Asset Ratio (DAR) variable is -5.916 with a significance value of 0.000 . The ttable value at the 5\% significance level and the degrees of freedom of $n-k-1=32-2-1=29$ is -2.02523 . Table 4 shows that the tcount value 
is greater than the ttable value with a significance level of 0.000 , so that hypothesis 1 of this study is accepted. Thus, it can be concluded that the Debt to Asset Ratio (DAR) has a negative and significant effect on financial performance as measured by Return On Assets (ROA).

\section{The Effect of LTDER on Financial Performance (ROA)}

In table 4 above, it can be seen that the tcount for the Long Term Debt to Equity Ratio (LTDER) variable is 1.598 . This value is smaller than the ttable value of 2.025. The significance value of the LTDER variable is 0.121 which is greater than the alpha value of 0.05 , so that hypothesis 2 proposed in the study is rejected, which means that the effect of Long Term Debt to Equity Ratio (LTDER) on Return On Assets (ROA) is not significant.

\section{F Test}

The statistical F test was conducted to test the effect of the X1 and X2 variables on the $\mathrm{Y}$ variable. The determination of the test criteria was based on the comparison between Fcount and Ftable. The test results are as follows:

Table 5. F Test Result

\begin{tabular}{|c|c|c|}
\hline Model & F & Sig \\
\hline Regression & 42,935 & 0,000 \\
\hline
\end{tabular}

Based on the results of the analysis above, the Fcount results are 42,935 with a significance value of 0.000 . The value of Ftable at the $5 \%$ significance level and the degrees of freedom $\mathrm{df} 1=\mathrm{k}=2$ and $\mathrm{df} 2$ $=\mathrm{n}-\mathrm{k}-1=32-2-1=29$ is 3.33. The value of Fcount is greater than the value of Ftable, then Fcount so that hypothesis 3 in this study is accepted. Thus, it can be concluded that the Debt to Asset Ratio (DAR) and Long Term Debt to Equity Ratio (LTDER) variables jointly affect the company's financial performance (ROA).

\section{DISCUSSION}

\section{The Effect of DAR and LTDER on Financial Performance}

The independent variable capital structure as measured by the Debt to Asset Ratio (DAR) and Long Term Debt to Equity Ratio (LTDER) jointly affect financial performance (ROA). The results of this study are in accordance with the research conducted by Nugraha (2013) and Anthonie et al., (2018) which showed the results of the influence of capital structure on financial performance. The results of this study are in accordance with the theory put forward by Modigliani and Miller that in conditions of taxation it is better for companies to use debt to improve the company's financial performance. This is because with the use of debt, the company will be able to reduce the amount 
of tax borne by the company so that the tax reduction will improve the company's performance in terms of profitability.

\section{Effect of DAR on Financial Performance (ROA)}

Debt to Asset Ratio (DAR) shows the total amount of debt that can be guaranteed by total assets. The higher the Debt to Asset Ratio (DAR) indicates the higher the risk faced by the company because debt carries a fixed interest consequence (Utama and Muid, 2014). The greater the DAR value also indicates that most of the capital owned by the company to finance the company's assets comes from debt. The results show that there is a negative influence between DAR and financial performance, which means that the smaller the company's debt will increase financial performance (ROA).

\section{The Effect of LTDER on Financial Performance}

Long Term Debt to Equity Ratio (LTDER) is a ratio used to compare the company's long-term debt to the company's total equity. Research conducted by Abor (2007) states that long-term debt tends to require more expensive costs, therefore if a company with a high proportion can cause a decrease in company profitability.

The results showed that the high and low Long Term Debt to Equity Ratio (LTDER) in plastic and packaging companies listed on the Indonesia Stock Exchange (IDX) for the 2012-2019 period did not have a significant effect on Return On Assets (ROA). This is not in accordance with the proposed hypothesis, namely the Long Term Debt to Equity Ratio (LTDER) has an effect on Return On Assets (ROA). This is because all companies have long-term debt that is smaller than their short-term debt.

The results of this study are in accordance with previous research conducted by Azis and Hartono (2017) and Nugraha (2013). In Azis and Hartono's research (2017) with the results of the Long Term Debt to Equity Ratio (LTDER) research, it has no effect on the company's financial performance. However, it is different from the research conducted by Ludjianto et al (2014) which showed that the Long Term Debt to Equity Ratio (LTDER) had a significant effect on financial performance. The results of this study indicate that if the company adds long-term debt it will be able to improve the company's financial performance.

\section{CONCLUSION}

Based on the results of the analysis in the previous chapter, several conclusions are obtained about the relationship between capital structure and financial performance in manufacturing companies in the plastic and packaging sector as follows: (1) Capital structure proxied by Debt to Asset Ratio (DAR) has a negative and significant effect on financial performance (ROA), meaning that the smaller the company's debt will increase the company's Return On Assets (ROA); (2) The effect of capital structure proxied by Long Term Debt to 
Equity Ratio (LTDER) is not significant on Return On Assets (ROA). This means that the increase in long-term debt does not affect the Return On Assets (ROA) because the company uses more short-term debt than long-term debt; (3) Debt to Asset Ratio (DAR) and Long Term Debt to Equity Ratio (LTDER) together (simultaneously) have an effect on Return On Assets (ROA). This is because the use of debt can reduce the tax burden so that by reducing taxes will improve performance in terms of profitability.

\section{RECOMMENDATION}

Based on the conclusions above, the recommendations for this research are; (1) Each company is expected to take into account the optimal capital structure to improve its financial performance. (2) Future research is expected to use other ratios besides DAR and LTDER as a proxy for capital structure.

\section{REFERENCES}

Abor, J. (2007). Debt Policy And Performance of SMEs Evidence From Ghanaian and South African Firms. 364-379. https://doi.org/10.1108/15265940710777315

Azis, A., \& Hartono, U. (2017). Pengaruh Good Corporate Governance, Struktur Modal, Dan Leverage Terhadap Kinerja Keuangan Perusahaan Pada Sektor Pertambangan Yang Terdaftar Di Bursa Efek Indonesia Tahun 2011-2015. Jurnal Ilmu Manajemen, 5(3), 1-13.

Binangkit, A. B., \& Raharjo, S. (2014). Pengaruh Struktur Modal Terhadap Kinerja Perusahaan Dan Harga Saham Pada Perusahaan Manufaktur Di Bursa Efek Indonesia. 1(2), 24-34.

Fachrudin.Khaira Amalia. (2011). Analisis Pengaruh Struktur Modal , Ukuran Perusahaan, dan Agency Cost Terhadap Kinerja Perusahaan.

Fadhilah Ansoriyah. (2012). Pengaruh Struktur Modal Terhadap Kinerja Keuangan Perusahaan: Studi Kasus Pada Perusahaan Sektor Pertambangan Yang Tercatat Di Bursa Efek Indonesia, 2005-2011. https://doi.org/https://doi.org.10.31685/kek.v16i1.20

Fahmi, I. (2015). Pengantar Manajemen Keuangan. Alfabeta: Bandung.

Ghozali, I. (2001). Aplikasi Analisis Multivariate Dengan Program SPSS. Badan Penerbit Universitas Diponegoro: Semarang.

Gitman, L. . (2003). Principle of Managerial Finance. 10, 235-245.

Hanafi, M. M. (2016). Manajemen Keuangan (Edisi 2). BPFEYogyakarta.

Harahap, S. S. (2013). Analisis Kritis Atas Laporan Keuangan. Rajawali Pers, Jakarta. 
Jumingan. (2011). Analisis Laporan Keuangan. Bumi Aksara: Jakarta.

Kasmir. (2019). Pengantar Manajemen Keuangan (Edisi Ke-2). Kencana: Jakarta.

Kristianti, I. P. (2018). Analisis Pengaruh Struktur Modal Terhadap Kinerja Keuangan Perusahaan. 2(1), 56-68. https://doi.org/10.29230/ad.v2i1.2222

Ludjianto, S. E., Handayani, S. R., \& Hidayat, R. R. (2014). Pengaruh Analisis Leverage Terhadap Kinerja Keuangan Perusahaan (Studi pada Perusahaan Property dan Real Estate yang Listing di BEI Tahun 2010-2012). Jurnal Administrasi Bisnis S1 Universitas Brawijaya, 8(1), 79708.

Margaretha, F. (2014). Dasar-Dasar Manajemen Keuangan. Dian Rakyat: Jakarta.

Modigliani, F., \& Miller, M. H. (1958). The American Economic Review. British Medical Journal, 2(3594), 952-953. https://doi.org/10.1136/bmj.2.3594.952

Munawir. (2004). Analisa Laporan Keuangan (Edisi 4). Liberty Yogyakarta.

Nugraha, A. (2013). Analisis Pengaruh Struktur Modal Terhadap Kinerja Perusahaan Yang Tergabung Dalam Indeks Kompas 100. Management Analysis Journal, 2(1), 1-7. https://doi.org/10.15294/maj.v2i1.1406

Sartono, A. (2012). Manajemen Keuangan. BPFE-Yogyakarta.

Tangkilisan. Hessel Nogi S. (2003). Memahami Kinerja Keuangan Perusahaan. Saint Joseph's University: Yogyakarta.

Widiyanti, M., \& Elfina, F. D. (2015). Pengaruh Leverage Terhadap Profitabilitas Pada Perusahaan Sub Sektor Otomotif dan Komponen Yang Terdaftar di Bursa Efek Indonesia. 